University of Nebraska - Lincoln

DigitalCommons@University of Nebraska - Lincoln

USDA Wildlife Services - Staff Publications

U.S. Department of Agriculture: Animal and Plant Health Inspection Service

2021

\title{
Impact of COVID-19 on the US and Texas Economy: A General Equilibrium Approach
}

\author{
Lirong Liu \\ Texas A\&M University Commerce \\ Steven S. Shwiff \\ Texas A\&M University, Steven.Shwiff@tamuc.edu \\ Stephanie A. Shwiff \\ USDA APHIS NWC, Fort Collins, CO, stephanie.a.shwiff@aphis.usda.gov \\ Maryfrances Miller \\ New Mexico State University, FrannieM@nmsu.edu
}

Follow this and additional works at: https://digitalcommons.unl.edu/icwdm_usdanwrc

Part of the Natural Resources and Conservation Commons, Natural Resources Management and Policy Commons, Other Environmental Sciences Commons, Other Veterinary Medicine Commons, Population Biology Commons, Terrestrial and Aquatic Ecology Commons, Veterinary Infectious Diseases Commons, Veterinary Microbiology and Immunobiology Commons, Veterinary Preventive Medicine, Epidemiology, and Public Health Commons, and the Zoology Commons

Liu, Lirong; Shwiff, Steven S.; Shwiff, Stephanie A.; and Miller, Maryfrances, "Impact of COVID-19 on the US and Texas Economy: A General Equilibrium Approach" (2021). USDA Wildlife Services - Staff Publications. 2545.

https://digitalcommons.unl.edu/icwdm_usdanwrc/2545

This Article is brought to you for free and open access by the U.S. Department of Agriculture: Animal and Plant Health Inspection Service at DigitalCommons@University of Nebraska - Lincoln. It has been accepted for inclusion in USDA Wildlife Services - Staff Publications by an authorized administrator of DigitalCommons@University of Nebraska - Lincoln. 


\title{
RESEARCH ARTICLE
}

Lirong Liu ${ }^{a}$, Steven Shwiff ${ }^{a}$, Stephanie Shwiff ${ }^{\text {b }}$, Maryfrances Miller ${ }^{c}$

\section{Impact of COVID-19 on the US and Texas Economy: A General Equilibrium Approach}

\begin{abstract}
This paper examines the impact of COVID-19 on the US and Texas economy using a computable general equilibrium model, REMI PI+. We consider three scenarios based on economic forecasts from various sources, including the University of Michigan's RSQE (Research Seminar in Quantitative Economics), IMF, and the Wi orld Bank. We report a GDP loss of \$106 million (a $6 \%$ decline) with 1.2 million jobs lost $(6.6 \%)$ in Texas in 2020 . At the national level, GDP loss is $\$ 996$ billion (a 5\% decline) with 11.5 million jobs lost (5.5\%) in the same year. By 2026, the aggregate total GDP loss in Texas ranges from $\$ 378$ to $\$ 629$ million. The estimated unemployment rate in Texas in 2021 ranges from $5 \%$ to $7.7 \%$, depending on modeling assumptions. The granularity of the CGE results allow examination of the most and least impacted industries. Health Care and Social Assistance, Construction, and Accommodation and Food Services incur the most job loss while State and Local Government and Farm will likely see an increase in jobs for 2020. These insights separate our work from most current impact studies.
\end{abstract}

Keywords COVID-19, computational general equilibrium model (CGE), economic impact

\section{JEL Classification A1, P4}

Received May 15, 2021

\footnotetext{
${ }^{\mathrm{a}}$ Department of Management and Economics, Texas A\&M University Commerce, Commerce, TX 75428, USA

${ }^{\mathrm{b}}$ USDA/APHIS/WS National Wildlife Research Center, Fort Collins, Colorado 80521, USA

${ }^{c}$ Department of Agricultural Economics and Agricultural Business, New Mexico State University, Las Cruces, NM 88003, USA

E-mail: lirong.liu@tamuc.edu (Lirong Liu, corresponding author), Steven.Shwiff@tamuc.edu (Steven Shwiff), Stephanie.A.Shwiff@aphis.usda.gov (Stephanie Shwiff), franniem@nmsu. edu (Maryfrances Miller)
} 


\section{Introduction}

The COVID-19 pandemic reached the U.S. in late January 2020 and spread widely across the nation within two months. By Late March, the U.S. had more confirmed cases than any other country in the world. In response to the outbreak, the U.S. declared a national emergency on March 13, 2020. Policies such as "shelter-in-place" and "social distance" have been implemented to cope with the spread. Texas is among the hardest hit states in the US but also one of the states that reopened the earliest. As of May 12, 2020, the total confirmed cases in the U.S. were 1.4 million, while almost 40 thousand were in Texas. As the virus continued to spread in Texas, state governor Greg Abbott issued an executive order on March 31, 2020 to, "direct all Texans to minimize non-essential gatherings and in-person contact with people who are not in the same household." However, beginning on May 1, 2020, retails stores, malls, restaurants, movie theaters, libraries and museums were allowed to operate with a $25 \%$ capacity limit. Texas is among several states that reopened as early as May $1,2020$.

While the world is coping with this fast-spreading virus and the resulting damage to impacted economies, an oil price war has added another economic shock. A Russia-Saudia Arabia oil price war was triggered in March of 2020. US oil prices fell by $34 \%$ during the first week of March and continued to fall. By April 20, the price of West Texas Intermediate (WTI, a benchmark in oil pricing) for May delivery became negative for the first time in history. Such a dual shock can have serious implications for Texas, as oil and gas are among the top industries in the state's economy.

On December 11, 2020, the long-expected COVID-19 vaccine developed by Pfizer was approved by FDA for emergency use. A week later, Moderna was approved by FDA. In February 2021, a third vaccine developed by Johnson \& Johnson was also approved by FDA. With limited quality initially, vaccine was only available to certain groups of people. As supply increased, the vaccine became available for general public in at the end of April 2021 in certain states, including Texas. The vaccine has substantially slowed down the spread of COVID-19. With the help of vaccination, Texas lifted mask mandated and fully reopened in March 2021.

The COVID-19 pandemic is impacting the world in unprecedented ways. As a 
result of the pandemic, world GDP saw an estimated 4.3\% decline in 2020, with a US GDP estimated to decline by 3.6\% (The World Bank, 2021). The economic impacts of COVID-19 are far-reaching and goes beyond 2020. This paper assesses the synergistic economic impact to the US and the Texas economy of COVID-19 coupled with the oil price shock for the duration of 2020-2026. We examine Texas economy in addition to the US economy because of two reasons. First, Texas economy is the second largest by GDP in the US and the ninth largest in the world. Yet, Texas is also one of the hardest hit states during the pandemic (Baker 2021). Second, the Texas economy relies heavily on the energy industry, which experienced severe impact due to the oil price shock. This is unique in comparison to other states in the US.

Past studies on the economic impact of pandemics have mainly focused on influenza outbreaks and vaccinations programs (Meltzer et al., 1999; Garrett, 2007; Brainerd and Siegler, 2003; Smith et al., 2011; Smith et al., 2010). Recently, several studies have examined the economic impact of COVID-19 since the outbreak. For example, McKibbin and Fernando (2020) estimate the impact of COVID-19 on the economies of G20 countries in 2020. Using a hybrid of dynamic stochastic general equilibrium and CGE model, they estimate a GDP loss between $0.1 \%$ to $8.4 \%$ in the US economy. Fernandes (2020) examines the impact of COVID-19 on different industries and countries and find the US GDP is projected to decline by $0.4 \%$ to $3.0 \%$ based on various scenarios. Rephann (2020) estimates the economic impact of COVID-19 for the Commonwealth of Virginia using a CGE model. This study finds that in 2020 in the moderate scenario, job loss is close to 300,000 and GDP loss is nearly \$18 billion, while under the severe scenario job loss exceeds 500,000 and GDP loss amounts to $\$ 40.7$ billion. International trade can be severely impacted by the COVID-19 outbreak. Baldwin and Tomiura (2020) provide an outlook on the impact of COVID on trade. Che et al (2020) analyze the impact on China exports by COVID-19 and find that exports to countries with high risk of spread experienced a larger decline. Other studies examine the impact of COVID-19 on other dimensions such as policy responses, financial risk, and production (see for examples Fornaro and Wolf, 2020; Barua 2020; Mann, 2020).

We contribute to the study of COVID-19 economic impact in several ways. First, we use a dynamic CGE model to estimate the economic impact in the year of the outbreak and also the years beyond the outbreak for a total of seven years 
from 2020 to 2026. The economic shock from the pandemic shifts the US and world economy to a new track and it may take years for the economy to return to normal. Thus, examining the long-lasting effects of the pandemic can provide a more complete picture of the economic impact. Second, in addition to the impact on GDP in the US and Texas, we examine the impact on employment by industry to provide a detailed description of the shocks to the economy. The granularity of the results provides economic impact at a disaggregated level and allows policy makers to see how impacts are distributed among various industries and occupations.

\section{Methodology}

The model used to estimate the economic impact of COVID-19 in the US and Texas is a dynamic CGE model, specifically, the REMI PI+ (Regional Economic Models, Inc. Policy Insight Plus) model, hereafter known as REMI. The REMI model is a major commercial input-output (IO) model developed by Regional Economic Models Inc. It is a multi-sector multi-region dynamic CGE model that is used for economic forecasts, policy analysis and economic impact analysis.

In comparison to other commercial and user developed CGE models, REMI provides dynamic multi-region model that provides estimation up to 60 years and fully captures the economic links across regions. The model is "a world -apart in complexity, reliance on interindustry linkages, and modeling philosophy" from other econometric models (Bolton, 1985). The REMI model is widely used by the governments for economic forecasting and planning, and it has also been used evaluating economic impacts in the literature (Ehlen, 2001; Loose et al., 2010; Livinggood et al., 2007; Weisbrod, 2008). The key component in REMI is the input-output model, which tracks the flows of goods and services among industries. Various assumptions are made regarding the nature of the utility and production functions and factor ownership, including firms maximizing profit and households maximizing utility. Figure 1 shows a graphic view of the structure of the CGE model in REMI. It has five major blocks with (1) Output, Labor and Capital Demand, (2) Population and Labor Supply, (3) Wages, Prices, and Costs, and (5) Market Shares. A total of 70 sectors are included in the input-output model. It is assumed that the economy is in equilibrium when a set of prices is attained for which the value of the income flow from firms to households is equal to the value of the money expenditure from households to firms. 
REMI MODEL Linkages (Excluding Economic Geography Linkagcs)

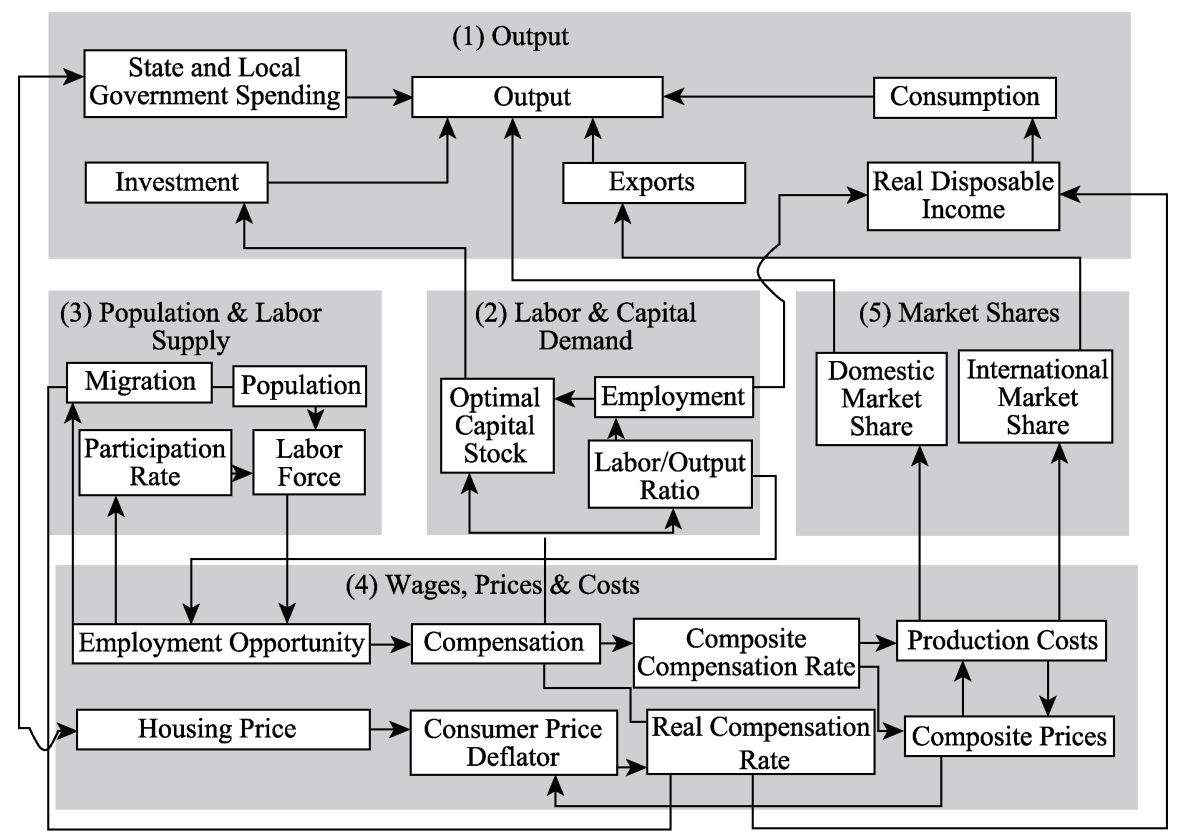

Figure 1 Output Input Model in REMI

Note: Figure 1 shows a graphic view of the structure of the CGE model in REMI. It has five major blocks with (1) Output, Labor and Capital Demand, (2) Population and Labor Supply, (3) Wages, Prices, and Costs, and (5) Market Shares. The arrows indicate the connection of each individual sectors in the economy.

National and regional control simulations are pre-built in REMI and act as baseline models. Such models incorporate macroeconomic statistics and forecasts that reflect current economic conditions and future projected economic growth. To examine effects of policy changes or economic shocks, new simulations are run, which shock the corresponding policy or economic variables. These simulation results can then be compared with the baseline model to examine the effects of the policy or shocks.

The REMI model is calibrated to regional conditions using several sources of data. The employment and income data are based on the Bureau of Economic Analysis (BEA) employment, wage, and personal income series, and the Bureau of the Census County Business Patterns (CBP) data. Output data come from regional employment data, the BEA Gross State Product series, and national output-to-employment ratios (Lynch, 2000). 
We obtain the REMI model for the nation and the state of Texas. Within the REMI setting, Texas is treated as one region and the rest of the US is lumped into one single region. Our analysis is based on GDP growth in 2020 and GDP forecasts for future years. Various organizations have published such forecasts based their own assumptions and considerations. Instead of using every forecast from these organizations, we obtained the GDP forecast from several reputable organizations, including the University of Michigan's RSQE (Research Seminar in Quantitative Economics), IMF and the World Bank. We then select the highest, the lowest, and the mean forecasts from the three organizations. Table 1 shows the list of the sources and their corresponding forecasts. In our simulation, we consider the following four scenarios:

- Scenario 0: the baseline case, pre-built in REMI and representing economic growth without a pandemic

- Scenario 1: the optimistic pandemic case, based on the highest forecasts (IMF) with an estimated GDP decline of $3.5 \%$ in 2020 and a projected GDP growth of 64. (2021) and 3.5 (2022).

- Scenario 2: the moderate pandemic case, based on the average rate of all four forecasts with an estimated GDP decline of 3.53\% in 2020 and a projected GDP growth of 4.9 (2021) and 3.6 (2022).

- Scenario 3: the severe pandemic case, based on lowest forecasts (World Bank) with an estimated GDP decline of 5.9\% in 2020 and a projected GDP growth of 3.5 (2021) and 3.3 (2022).

Table 1 Source of GDP Forecasts

\begin{tabular}{ccccc}
\hline Source & Date of Release & $\mathbf{2 0 2 0}$ & $\mathbf{2 0 2 1}$ & $\mathbf{2 0 2 2}$ \\
\hline IMF & April, 2021 & -3.5 & 6.4 & 3.5 \\
RSQE & February, 2021 & -3.5 & 4.8 & 3.9 \\
World Bank & January, 2021 & -3.6 & 3.5 & 3.3 \\
Average & & -3.53 & 4.9 & 3.57 \\
\hline
\end{tabular}

Note: Table 1 shows the estimated GDP growth in 2020 and the projected GDP growth in 2021 and 2022 from various publicly available sources, including IMF, University of Michigan's Research Seminar in Quantitative Economics (RSQE), and the World Bank.

Each of the corresponding COVID-19 GDP growth forecasts represented in Scenarios 1-3 represents a new shock to the national economies and the Texas economy. Within the REMI PI+ framework, this creates a comparison between 
the pre-COVID-19 baseline results (scenario 0) and the three new post COVID-19 simulations (Scenarios 1-3). The differences between the pre and post COVID-19 simulations represents the impact of COVID-19 at both the national and Texas regional level.

The REMI model settings allow for shocks to the overall GDP level. However, that will assume uniformed impacts on all 70 sectors in REMI. To capture the differential impact of COVID-19 to the various sectors and industries in the economy, we calibrate our model using the sector-level economic forecasts published by RSQE during the pandemic (RSQE, 2020). The publication provides growth rate forecasts for the overall national GDP growth rate and also the growth rate forecasts for individual sectors. We assume that for any given level of GDP growth rate forecasts, the change in GDP in individual sectors is proportional to those forecasts by RSQE. For example, the RSQE forecast for the overall GDP growth for 2020 is $-2.37 \%$ and the growth rate forecast for natural gas is $-0.08 \%$. Then for an overall GDP growth of $-3.6 \%$ (World Bank), the corresponding growth rate for natural gas is $(-0.08 \%) /(-2.37 \%) *(-3.6 \%)=$ $-0.12 \%$.

Using the settings described above, we first run four rounds of simulations corresponding to the four scenarios at the national level. Then based on the input-output model embedded in REMI, we run simulations at regional level, Texas, for the four scenarios.

Results are presented at the national, regional and sectorial level, highlighting the sectors of the Texas economy that are more impacted than others as well as which may recover more quickly. This differs from most current analysis which has focused only on the aggregated impacts. A technical note on REMI simulation methodology is included in the Appendix A. While REMI is capable of making forecasts to 2060, results are limited to 2020-2026. For 2022-2026, it is assumed the economy returns to normal.

\section{Results and Discussion}

\subsection{Impact on GDP and job loss}

Results are listed in Tables 2-5. Table 2 shows the changes in GDP and number of jobs at the national level while Table 3 shows the changes in Texas. Table 4 reports the most and least impacted industries in terms of employment and Table 
5 reports the unemployment rate in 2021.

Table 2 National GDP and Employment Impact

\begin{tabular}{ccccccccc}
\hline Indicators & 2020 & 2021 & 2022 & 2023 & 2024 & 2025 & 2026 & Cumulative \\
\hline \multicolumn{7}{c}{ Scenario 1 Optimistic } \\
\hline $\begin{array}{c}\text { Job } \\
\text { (thousand) }\end{array}$ & $-11,540$ & $-2,234$ & 2,206 & 1,776 & 1,131 & 447 & 145 & \\
Job change & $-5.52 \%$ & $-1.09 \%$ & $1.06 \%$ & $0.85 \%$ & $0.54 \%$ & $0.21 \%$ & $0.07 \%$ & \\
$\begin{array}{c}\text { GDP } \\
\text { (\$ billion) }\end{array}$ & -996 & -102 & 298 & 284 & 242 & 197 & 190 & 112 \\
$\begin{array}{c}\text { GDP } \\
\text { change }\end{array}$ & $-5.14 \%$ & $-0.52 \%$ & $1.49 \%$ & $1.40 \%$ & $1.17 \%$ & $0.93 \%$ & $0.89 \%$ & \\
$\begin{array}{c}\text { Job } \\
\text { (thousand) }\end{array}$ & $-11,540$ & $-5,115$ & -561 & $-1,018$ & $-1,688$ & $-2,392$ & $-2,712$ & \\
Job change & $-5.52 \%$ & $-2.48 \%$ & $-0.27 \%$ & $-0.49 \%$ & $-0.81 \%$ & $-1.14 \%$ & $-1.29 \%$ & \\
$\begin{array}{c}\text { GDP } \\
\text { (\$ billion) }\end{array}$ & -996 & -379 & 29 & 7 & -42 & -95 & -108 & $-1,584$ \\
$\begin{array}{c}\text { GDP } \\
\text { change }\end{array}$ & $-5.14 \%$ & $-1.93 \%$ & $0.15 \%$ & $0.04 \%$ & $-0.20 \%$ & $-0.45 \%$ & $-0.51 \%$ & \\
$\begin{array}{c}\text { Job } \\
\text { (thousand) }\end{array}$ & $-11,760$ & $-8,124$ & $-4,233$ & $-4,724$ & $-5,426$ & $-6,157$ & $-6,498$ & \\
Job change & $-5.63 \%$ & $-3.95 \%$ & $-2.04 \%$ & $-2.27 \%$ & $-2.60 \%$ & $-2.94 \%$ & $-3.09 \%$ & \\
$\begin{array}{c}\text { GDP } \\
\text { (\$ billion) }\end{array}$ & $-1,015$ & -666 & -319 & -351 & -410 & -473 & -496 & $-3,730$ \\
$\begin{array}{c}\text { GDP } \\
\text { change }\end{array}$ & $-5.23 \%$ & $-3.38 \%$ & $-1.60 \%$ & $-1.73 \%$ & $-1.98 \%$ & $-2.24 \%$ & $-2.31 \%$ & \\
\hline
\end{tabular}

Note: Table 2 shows the GDP and job loss at the national level from 2020 to 2026. Negative numbers indicate loss in GDP or the number of jobs. Changes in GDP and employment at the national level in comparison to the standard control which assumes no COVID-19 outbreak.

Since the estimated GDP growth for 2020 from all three sources is around $-3.5 \%$, the estimated GDP and job losses in 2020 is virtually the same under the optimistic, moderate and severe scenarios. At the national level, about 11.5 million or $5.5 \%$ of the jobs and $\$ 996$ billion or $5 \%$ in GDP are lost in $2020 .{ }^{1}$ In Texas, the job loss is 1.2 million or $6.58 \%$ and the loss in GDP is $\$ 106$ billion in

\footnotetext{
${ }^{1}$ Note that the GDP loss reported here refer to the loss in comparison to the baseline model without COVID-19. The negative GDP growth rate entered in REMI input refers to the change in GDP in 2020 in comparison to GDP in 2019. Since the baselines are different, these two percentages, GDP loss and GDP growth are not directly comparable.
} 
2020 , equivalent to a $5.89 \%$ decline.

Table 3 Texas GDP and Employment Impact

\begin{tabular}{ccccccccc}
\hline & 2020 & 2021 & 2022 & 2023 & 2024 & 2025 & 2026 & Cumulative \\
\hline $\begin{array}{c}\text { Job } \\
\text { (thousand) }\end{array}$ & $-1,210$ & -656 & -358 & -443 & -533 & -612 & -655 & \\
Job change & $-6.58 \%$ & $-3.60 \%$ & $-1.94 \%$ & $-2.39 \%$ & $-2.85 \%$ & $-3.25 \%$ & $-3.45 \%$ & \\
$\begin{array}{c}\text { GDP } \\
\text { ( billion) }\end{array}$ & -106 & -53 & -30 & -37 & -45 & -52 & -55 & -378 \\
$\begin{array}{c}\text { GDP } \\
\text { change }\end{array}$ & $-5.89 \%$ & $-2.88 \%$ & $-1.61 \%$ & $-1.92 \%$ & $-2.29 \%$ & $-2.59 \%$ & $-2.69 \%$ & \\
$\begin{array}{c}\text { Job } \\
\text { (thousand) }\end{array}$ & $-1,210$ & -839 & -517 & -599 & -691 & -777 & -827 & \\
Job change & $-6.58 \%$ & $-4.61 \%$ & $-2.80 \%$ & $-3.23 \%$ & $-3.70 \%$ & $-4.13 \%$ & $-4.36 \%$ & \\
$\begin{array}{c}\text { GDP } \\
\text { (\$ billion) }\end{array}$ & -106 & -71 & -46 & -53 & -62 & -70 & -75 & -484 \\
$\begin{array}{c}\text { GDP } \\
\text { change }\end{array}$ & $-5.89 \%$ & $-3.87 \%$ & $-2.47 \%$ & $-2.78 \%$ & $-3.16 \%$ & $-3.50 \%$ & $-3.64 \%$ & \\
$\begin{array}{c}\text { Job } \\
\text { (thousand) }\end{array}$ & $-1,235$ & $-1,041$ & -756 & -833 & -927 & $-1,018$ & $-1,077$ & \\
Job change & $-6.72 \%$ & $-5.72 \%$ & $-4.10 \%$ & $-4.50 \%$ & $-4.96 \%$ & $-5.41 \%$ & $-5.67 \%$ & \\
$\begin{array}{c}\text { GDP } \\
\text { (\$ billion) }\end{array}$ & -108 & -91 & -69 & -77 & -86 & -96 & -102 & -629 \\
$\begin{array}{c}\text { GDP } \\
\text { change }\end{array}$ & $-6.01 \%$ & $-4.94 \%$ & $-3.70 \%$ & $-3.99 \%$ & $-4.39 \%$ & $-4.76 \%$ & $-4.95 \%$ & \\
\hline
\end{tabular}

Note: Table 3 shows the GDP and job loss in Texas from 2020 to 2026. Negative numbers indicate loss in GDP or the number of jobs. Changes in GDP and employment at the national level in comparison to the standard control which assumes no COVID-19 outbreak.

During the recovery period, the projected recovery rates differ significantly across the three sources we considered, IMF, RSQE, and the World Bank. Under the optimistic scenario, with the highest recovery rate of $6.4 \%$ in 2021 and $3.5 \%$ in 2022 (projected by IMF), job loss and GDP loss are reduced to 2.2 million and $\$ 102$ billion in 2021 at the national level. Starting from 2022, the number of jobs and GDP are both fully recovered and start to grow. In comparison, economic recovery In Texas is much slower, both the numbers of the jobs and GDP continue to be below the corresponding pre-COVID baseline levels. Job loss in 
2021 and 2022 is projected to be 0.7 and 0.4 million, while GDP loss in these two years is $\$ 53$ and $\$ 30$ billion, respectively. By 2026, the cumulative GDP loss in Texas is $\$ 378$ billion.

Table 4 Impact by Industries in 2020, Number of Job Change in Thousand

\begin{tabular}{lc}
\hline Top Five & Number of Jobs \\
\hline Health care and social assistance & -206 \\
Construction & -147 \\
Accommodation and food services & -119 \\
Other services (except public administration) & -109 \\
Finance and insurance & -96 \\
Bottom Five & \\
Federal civilian & 2 \\
Federal military & 3 \\
Forestry, fishing, and hunting & 4 \\
Farm & 17 \\
State and local government & 50 \\
\hline
\end{tabular}

Note: Table 4 shows the most and least impacted industries in terms of employment in Texas in 2020.

Table 5 Unemployment Rate 2020

\begin{tabular}{cccc}
\hline & Optimistic & Moderate & Severe \\
\hline National & & & \\
\hline Number of jobs & 203,634 & 200,753 & 197,744 \\
Labor force & 163,747 & 163,747 & 163,747 \\
Unemployment rate & $4.73 \%$ & $6.08 \%$ & $7.49 \%$ \\
Texas & & & \\
Number of jobs & 17,541 & 17,358 & 17,156 \\
Labor force & 14,078 & 14,051 & 13,957 \\
Unemployment rate & $5.01 \%$ & $6.35 \%$ & $7.76 \%$ \\
\hline
\end{tabular}

Note: Table 5 shows the number of jobs and unemployment rate in 2021 at the national level and in Texas.

Under the moderate scenario, with a GDP growth rate of $4.9 \%$ and $3.6 \%$ in 2021 and 2022, the national economy will not fully recover within our estimation 
period. In the post-pandemic recovery, approximately 5 million jobs $(2.48 \%)$ and $\$ 379$ billion (1.93\%) in GDP will be lost in 2021 at the national level. In Texas, about 0.7 million (3.6\%) jobs will be lost and the GDP loss amounts to $\$ 53$ million (a $2.9 \%$ decline) in 2021, in comparison to the baseline model without the outbreak. However, since the recession in 2020 sets the GDP to a much lower base, the economy will grow with a much lower magnitude during the post-pandemic recovery. By 2026, the cumulative GDP loss is $\$ 1.584$ billion at the national level and $\$ 484$ in Texas.

Under the severe scenario, the post-pandemic recovery is much slower. In 2021, almost 8 million jobs (4\%) and $\$ 666$ billion (3.4\%) in GDP are lost nationwide. The Texas job loss is 1 million or $5.7 \%$ and the GDP loss is as high as $\$ 91$ billion or $5 \%$. By 2026, the cumulative GDP loss in Texas amounts to $\$ 629$ billion.

The Texas economy is the second largest in the U.S with a regional GDP of $\$ 1.8$ trillion in 2018. Overall, the impact of the pandemic in Texas is significant, accounting for more than $10 \%$ of the national GDP loss. In comparison to the impact on the national economy, the percentages of GDP loss and job loss in Texas are above the national level losses, suggesting the severe impact to the Texas economy as a result of both the pandemic and oil shock.

\subsection{Job Loss by Industries}

Next, we examine job loss by industries. Table 4 shows the top five and bottom five industries in job loss in Texas in 2020. Health care and social assistance ranks the first, with 206 thousand jobs lost in Texas. This may first appear to be conflicting with the ongoing pandemic since more health care are needed with the outbreak. However, according to McDermott and Cox (2020), more than 1.5 million healthcare jobs were lost from February through April 2020. Due to the concerns on hospitable being overwhelmed by COVID-19 cases, many "non-emergency, elective, or routine medical serves were delayed or cancelled" (McDermott and Cox, 2020). Construction and Accommodation and food services also appear on the top list, ranked the second and third, with 147 thousand and 119 thousand job losses respectively. New construction seems most negatively impacted initially by the economy lockdown and financial difficulties due to job loss. Accommodation and food services is relatively labor-intensive. 
The Starting from March 2020, restaurants and bars are either temporarily closed or only provide taking-out orders during the pandemic. According to a report from the National Restaurant Association (2020), "restaurants have lost nearly three times more jobs than any other industries since the beginning of the coronavirus outbreak." Thus, it is not surprising that Food services and drinking places incur the most job loss.

Although the overall Texas economy experiences a severe recession in early 2020, certain industries experience mild or no job loss, and some even gained jobs. State and local government sees an increase in job by 50 thousand. In general, some of the agricultural industries also experience job gains, including Forestry and logging; Fishing, and Farm. Social distancing and lockdown most likely have a limited impact on such industries.

\subsection{Unemployment Rate}

All economies are interconnected economic systems at the national, state, and local levels. This is reflected in the fact that some industries may gain workers while others lose them. This dynamic reflects the nature of labor mobility. Parts of the workforce are thus pushed to industries that are hiring from those that are not. The employment change reported in the model reflects the percentage and the number jobs lost due to the pandemic outbreak. According to US Department of Labor, the annual unemployment rate in the US is $8.1 \%$ in 2020 , increased by 4.4 percent points from the previous year. Texas unemployment rate in 2020 is $7.6 \%$, slightly lower than the national average. With the economy recovers from the pandemic in 2021, employment may improve. However, given the severe impacts from the pandemic, recovery in employment may take longer than under other scenarios or shocks. We convert the job loss to an unemployment rate in 2021 and report the results in Table 5. Appendix B provides details the conversion method. ${ }^{2}$

At the national level, the annual unemployment rate in 2021 ranges from $4.7 \%$ to $7.5 \%$. According to US Department of Labor, the national unemployment rate in April 2021 is 6.9\%. The Texas annual unemployment rate is between 5\% and

\footnotetext{
${ }^{2}$ Given the method we used, the converted unemployment rate may underestimate the actual rate.
} 
$7.7 \%$ in 2020 , slightly above the national level. This corresponds to our findings in job loss in that the job loss and GDP loss in Texas are higher than the national level in percentage. Although the projected unemployment rate at the national level and in Texas are lower than the rate in 2021 even under the severe case, the projected unemployment rates in 2021 are still much higher than the pre-pandemic levels. This suggests that the recovery of the economy and employment can take years.

The outbreak of COVID-19 is a rapidly evolving situation. The goal of this analysis is to provide the best estimates based on information currently available. Future changes in the disease spread and policy responses can affect the economy and may require further adjustments.

\section{Conclusion}

This paper estimates the synergistic economic impact of COVID-19 and an oil price shock on the US economy and Texas economy. To provide a more complete picture and to facilitate comparison, we report the economic impact both at the national level and the state level. Results indicate that Texas face a tougher job in economic recovery than the national economy.

The simulations presented here offer some insight into the damage being done to the economy. As policy makers look to support recovery and suppress the impact of COVID-19, paying attention to health care and food services sectors, will provide the most economic relief to the hardest hit portions of the economy.

The simulations presented here provide some general conclusions that can be drawn from the examination of COVID-19 impact on Texas and the nation. First, the role technology will play in the future will be greater. E-commerce, online learning, tele-medicine, and work from home have proven to be more viable than expected. This may fundamentally change consumer behavior and how the economy evolves both positively or negatively. Second, globalization and global supply chains have exposed vulnerabilities. Major changes in global supply chain utilization and management should be expected in the future. As the negative impacts associated with COVID-19 persist and reopening the economy get delayed, it may be the case that the most pessimistic forecast associated with this study is the most accurate. 


\section{Reference}

Baldwin R, Tomiura E (2020). Thinking ahead about the trade impact of COVID-19. In R. Baldwin, B. W. di Mauro (ed.), Economics in the Time of COVID-19. London: CEPR Press.

Barua S (2020). Understanding coronanomics: The economic implications of the Coronavirus (COVID-19) pandemic. Available at SSRN: http://dx.doi.org/10.2139/ssrn.3566477, accessed June 5, 2021.

Baker J. (2021). Texas ranked third among the hardest hit states financially. Available at: https:/www.kxxv.com/rebound/coronavirus-money-help/texas-ranked-third-among-the-har dest-hit-states-financially, accessed June 5, 2021.

Brainerd E, Siegler M V (2003). The economic effects of the 1918 influenza epidemic. Discussion Paper no. 3791, Centre Econ. Policy Res., Paris.

Bolton R (1985). Regional econometric models. Journal of Regional Science, 25: 495- 520.

Che Y, Liu W, Zhang Y, Zhao L (2020). China's exports during the global COVID-19 pandemic. Frontiers of Economics in China, 15(4): 541-574.

Ehlen M A (2001). The economic impact of manufacturing extension centers. Economic Development Quarterly, 15(1), 36-44.

Fernandes N (2020). Economic effects of Coronavirus outbreak (COVID-19) on the world economy. https://ssrn.com/abstract=3557504.

Fornaro L, Wolf M (2020). Covid-19 Coronavirus and macroeconomic policy. Working Paper. Available at: https://econ-papers.upf.edu/papers/1713.pdf, accessed June 6, 2021.

Garrett T A (2013). Economic Effects of the 1918 Influenza Pandemic: Implications for a Modern-Day Pandemic. DIANE Publishing Company, ISBN: 1457847574 , 9781457847578.

Lynch T (2000). Analyzing the economic impact of transportation projects using RIMS II, IMPLAN and REMI. https://trid.trb.org/view/706644, accessed June 5, 2021.

Livingood W C, Coughlin S, Bowman W, Bryant III T, Goldhagen J (2007). Application of economic impact analysis to a local public health agency and its "academic health department". Public Health Reports, 122(1), 27-36.

Smith B J, Starks S J, Loose V W, Brown T J, Warren D E, Vargas V N (2010). Economic and policy implications of pandemic influenza. United States: N. p., 2010. Web. doi:10.2172/ 991843.

Mann C L (2020). Real and financial lenses to assess the economic consequences of COVID-19. In: Baldwin, B. W. di Mauro (ed.), Economics in the Time of COVID-19. London: CEPR Press.

McDermott D, Cox C (2020). What impact has the Coronavirus pandemic had on healthcare employment? https:/www.healthsystemtracker.org/chart-collection/what-impact-has-thecoronavirus-pandemic-had-on-healthcare-employment/\#item-start, accessed May 1, 2021.

McKibbin R F, Fernando R (2020). The global macroeconomic impacts of COVID-19: Seven scenarios. COVID Economics: Vetted and Real Time Papers, 10, London, Centre for 
Economic Policy Research, 116-156.

Meltzer M I, Cox N J, Fukuda K (1999). The economic impact of pandemic influenza in the United States: Priorities for intervention. Emerging Infectious Diseases, 5(5): 659-671.

National Restaurant Association (2020). Three decades of restaurant jobs were lost during the last two months. https://restaurant.org/education-and-resources/resource-library/threedecades-of-restaurant-jobs-were-lost-during-the-last-two-months

Office of the Texas Governor (2020). Governor Abbott issues executive order, implements statewide essential services and activities protocols. March 31, 2020. https:/gov.texas.gov/ news/post/governor-abbott-issues-executive-order-implements-statewide-essential-servicesand-activities-protoc-ols.

Rephann T J (2020). Covid-19 economic and tax revenue impacts: Estimates for the commonwealth of Virginia and localities. 10.13140/RG.2.2.20087.57764. Researchgate. net. Also available at: https://www.nelsoncounty-va.gov/wp-content/uploads/COVID-economics-CEPS.pdf, accessed May 31, 2020

Smith R D, Marcus R K, Barnett T (2011). Estimating the economic impact of pandemic influenza: An application of the computable general equilibrium model to the UK. Social Science and Medicine, 73(2): 235-244.

RSQE, University of Michigan (2020). Update April 9: The U.S. and Michigan Economic Outlook for 2020-2022. Available at: https://sa.umich.edu/content/dam/econ-assets/ Econdocs/RSQE\%20PDFs/RSQE_Forecast_Update_(2020.04).pdf, accessed May 31, 2020

Svitek P (2020). Gov. Greg Abbott to let restaurants, movie theaters and malls open with limited capacity Friday, Texastribune. https:/www.texastribune.org/2020/04/27/texasreopening-coronavirus-greg-abbott, accessed May 31, 2020

Weisbrod G (2008). Models to predict the economic development impact of transportation projects: Historical experience and new applications. The Annals of Regional Science, 42(3), 519-543.

The World Bank (2021). Global economic prospects. https://www.worldbank.org/en/ publication/global-economic-prospects, accessed May 1, 2021.

\section{Appendix}

\section{A Note on REMI Simulation Methodology}

In the most recent REMI update, the RSQE forecast is adjusted and adopted in the modeling options. ${ }^{3}$ Thus, we can conduct the simulation at the national and regional level directly for our optimistic scenario. In the REMI update, the GDP

\footnotetext{
${ }^{3}$ In addition to adopting the GDP forecast from RSQE, further adjustments are made to Income, Unemployment and Labor Productivity. Since the RSQE forecast represents our optimist scenario, we also adopt the same adjustments in these categories in the other two scenarios so that these three scenarios are comparable.
} 
growth rate forecasted by RSQE is allocated to the 85 major sectors (named components in REMI) with adjusted component-level growth rates. In comparison to a uniform component-level growth rate, such adjusted growth rate allows for sector-specific changes. This better reflects how each sector in the economy is impacted by the pandemic and policies such as lockdown and social distancing. For example, certain sectors face complete shutdown while others face limited business activities. Work-from-home can be easily adopted for certain businesses but may not be feasible for others.

To implement other GDP growth rate forecasts in REMI, we adopt a similar method as the one in the REMI update. We first obtain the component-level growth rate from the REMI update, then rescale them based on the GDP growth rates. This also allows us to compare results from the three scenarios directly.

\section{B Note on Converting Job Loss to Unemployment Rate}

The employment change reported in REMI reflects the percentage and the number jobs lost due to the pandemic outbreak. We convert it to unemployment rates using the method below. Since people can have more than one job, the percentage change in job loss is not equivalent to the percentage change in unemployment rate. We first obtain the annual unemployment rate of $3.66 \%$ in 2019 from Bureau of Labor Statistics. Then using the labor force and total number of jobs from REMI, we can find out the average number of jobs each employee has using the following equations.

Number of people employed ${ }_{2019}=$ Labor force $_{2019} *(1$-umemployment rate $_{2019)}$

Jobs per person employed ${ }_{2019}=$ Total number of $\mathrm{jobs}_{2019} /$ Number of people employed 2019

Assuming that the number of jobs per person employed remains the same in 2020, we calculate the unemployment rate as:

Annual unemployment rate $_{2020}=1-\left(\right.$ Total number of jobs $_{2020} / \mathrm{Jobs}$ per person employed ${ }_{2019}$ ) 
The same method is used to convert the job loss to unemployment rate both at the national level and the state level, assuming that the unemployment rate in Texas in 2019 is the same as that of the national rate in 2019. Note that during the pandemic outbreak, it is possible that some of the jobs lost are from people who have more than one job. Thus, the number of jobs per person employed can be lower than the ratio estimated using the 2019 numbers when the economy is under normal conditions. Therefore, the converted unemployment rate tends to underestimate the actual unemployment rate. 